\title{
Outlook on the Carbon-Based Materials for Heavy Metal Removal
}

\author{
Haziqatulhanis Ibrahim 1(D), Norazlianie Sazali ${ }^{1, * \mathbb{D}}$, Wan Norharyati Wan Salleh ${ }^{2 \mathbb{D}}$, Nor Hasrul \\ Akhmal Ngadiman ${ }^{3(\mathbb{D})}$, Nor Akmal Fadil ${ }^{4}{ }^{(\mathbb{D}}$, Zawati Harun ${ }^{5(\mathbb{D}}$ \\ 1 College of Engineering, Universiti Malaysia Pahang, 26300 Gambang, Pahang, Malaysia; \\ haziqahanis.ibrahim@gmail.com (H.I.); azlianie@ump.edu.my (N.S.); \\ 2 Advanced Membrane Technology Research Centre (AMTEC), School of Chemical and Energy, Faculty of Engineering, \\ Universiti Teknologi Malaysia, 81310 Skudai, Johor Darul Takzim, Malaysia; hayati@ petroleum.utm.my (W.N.W.S.); \\ 3 Block C23 331, School of Mechanical Engineering, Faculty of Engineering, Universiti Teknologi Malaysia, 81310 Skudai, \\ Johor Darul Takzim, Malaysia; norhasrul@utm.my (N.A.N.); \\ 4 Materials Research and Consultancy Group, School of Mechanical Engineering, Faculty of Engineering, Universiti \\ Teknologi Malaysia, 81310 Skudai, Johor Darul Takzim, Malaysia.; norakmal@utm.my (N.A.F.); \\ 5 Faculty of Mechanical and Manufacturing Engineering, Universiti Tun Hussein Onn Malaysia, 86400 Parit Raja, Batu \\ Pahat, Johor Darul Takzim, Malaysia.; zawati@uthm.edu.my (Z.H.); \\ * Correspondence: azlianie@ump.edu.my (N.S.);
}

Scopus Author ID 57192717612

Received: 28.06.2021; Revised: 25.08.2021; Accepted: 28.08.2021; Published: 18.10.2021

\begin{abstract}
Carbon-based materials, including graphene (GR), carbon nanotubes (CNTs), activated carbon, and biochar, are the most common materials often applied to separate heavy metals from the water stream. A key feature of carbon adsorbent is the functional group of its adjustable surfaces. Both GR and CNTs exhibit the most favorable materials and may be the right choice in the future because of their excellent nature and unique structure. In order to commercialize the use of carbon absorbent in the removal of heavy metals, the mechanism of adsorption of carbon on heavy metals must be fully understood. In view of the good properties of carbon-based materials, a detailed study of their characteristics and synthesis, and modifications should be highlighted. Therefore, this article will discuss the properties, modifications, and use of carbon-based materials as adsorbents for various hazardous metal ions.
\end{abstract}

Keywords: carbon materials, graphene oxide; carbon nanotubes; heavy metal removal; adsorption mechanism.

(C) 2021 by the authors. This article is an open-access article distributed under the terms and conditions of the Creative Commons Attribution (CC BY) license (https://creativecommons.org/licenses/by/4.0/).

\section{Introduction}

Anthropogenic impacts derived from machinery manufacturing, fossil fuel combusting, oil refining, electroplating, and electronic production has triggered ever more toxic heavy metals being discharged into the mainland. Directly, the quality of the water is also being affected. As mentioned by United Nations, about $80 \%$ of all industrial and municipal wastewater in the developing world is discharged to the mainstream without any pre-treatment process [1-3]. Unlike other pollutants of the environment, poisonous heavy metals are invincible because they cannot be chemically or biologically destroyed. Due to the high level of toxicity, many heavy metal ions can give toxic effects even at low concentrations, interrupting normal human body activities and initiating the odd diseases to even death [4-6]. Particularly, in developing countries, the effects of increased pollution will be a major problem as they do not have the resources to treat contaminated water effectively. According to the https://biointerfaceresearch.com/ 
World Health Organization (WHO), around 844 million people cannot access basic drinking water, and 230 million spend more than 30 minutes daily collecting water supplies from enhanced water sources such as protected wells, rainwater, and boreholes [7]. These adverse conditions have led to water-related diseases, especially in the affected countries. According to WHO data, each year, about 1.60 million people die from diarrhea, and $90 \%$ of deaths occur in children under 5. Thus, strict standards were applied in most countries to control the heavy metal discharges into the water mainstream, which gives a stressful challenge for water treatment technologies.

Many technologies and processes have been introduced in heavy metal removal applications, such as membrane technology, ion exchange, coagulation-flocculation, adsorption, and precipitation [8-12]. Based on all the mentioned processes, the adsorption via based-carbon materials is mentioned as the utmost practical and low-cost technique. Carbon materials can be sourced from different types of materials, including activated carbon (AC), biochar, carbon nanotubes (CNTs), and graphene oxide (GO). All these mentioned materials have been majorly researched for the removal of heavy metals. Each type of material possesses a unique structure that can be further modified to be incorporated in the adsorption process to optimize the adsorption capacity of metal ions. Consequently, one main key of research is to deal with the modification of carbon materials to improve the function of the natural structure to adsorb the targeted metal ions. The main objective of this work is to afford a detailed review of current research regarding carbon-based materials as the adsorbent in terms of the adsorption mechanism, modification of carbon adsorbents, main adsorption parameters, and the performance of heavy metals removal.

\section{Removal of Heavy Metals by Adsorption}

Generally, heavy metals have an atomic weight of 63.5 to 200.6 with a greater density of more than $5 \mathrm{~g} / \mathrm{cm}^{3}$ [13]. Due to the toxicity of heavy metals, they can be contaminated even in small concentrations in any context of various types of industrial activities $[3,5,8,14]$. Table 1 shows the most common types of heavy metals, including sources of heavy metals, human health effects, and Maximum Contaminant Level (MCL) from the United States Environment Protection Agency (USEPA) and WHO. The hazardousness of heavy metals has been repeatedly mentioned by many researchers. As mentioned by Fiyadh et al., arsenic (As) is considered the most toxic heavy metal because it can cause many adverse effects on organisms [15]. The presence of As can be detected in various forms and levels of toxicity. Exposure to humans can cause a variety of diseases, including cancer, bladder, and skin problems [5,16]. A range of techniques has been introduced to remove heavy metals from water, such as oxidation [17-19], membrane technologies [20-23], ion exchange [24-26], precipitation [27,28], and photocatalysis $[29,30]$. Nevertheless, each of the methods mentioned has some limitations. For example, the precipitation technique will produce some hazardous by-products as they require further treatment. Meanwhile, the ion exchange process also produces some disadvantages due to the lack of recyclability. The major limitation in membrane processes relates to the cost and disposal of post-treatment waste materials. As Abbas and his team have studied, the electrodialysis process is quite favorable but requires considerable energy use and high operating costs [31]. In addition, some heavy metals are found in the soil, so it requires proper treatment. As there are many drawbacks to the aforementioned method, effective alternative methods and technologies to remove heavy metals need to be proposed. 
Table 1. The common types of heavy metals are found in the water stream.

\begin{tabular}{|c|c|c|c|c|c|}
\hline \multirow[t]{2}{*}{ Heavy metal } & \multirow[t]{2}{*}{ Sources } & \multirow[t]{2}{*}{ Health effects } & \multicolumn{2}{|c|}{ MCL (mg/L) } & \multirow[t]{2}{*}{ Ref. } \\
\hline & & & USEPA & WHO & \\
\hline Arsenic (As) & $\begin{array}{l}\text { Electronic } \\
\text { production }\end{array}$ & $\begin{array}{l}\text { Skin damage } \\
\text { Circulatory system issues }\end{array}$ & 0.010 & 0.010 & {$[5,16,32]$} \\
\hline Cadmium $(\mathrm{Cd})$ & $\begin{array}{l}\text { Various chemical } \\
\text { industries }\end{array}$ & $\begin{array}{l}\text { Kidney damage, } \\
\text { Carcinogenic }\end{array}$ & 0.005 & 0.003 & [33-35] \\
\hline Chromium $(\mathrm{Cr})$ & $\begin{array}{l}\text { Steel } \\
\text { manufacturing }\end{array}$ & $\begin{array}{l}\text { Allergic dermatitis, diarrhea, } \\
\text { nausea, vomiting }\end{array}$ & 0.1 & 0.05 & [36-39] \\
\hline Copper $(\mathrm{Cu})$ & $\begin{array}{l}\text { Household } \\
\text { plumbing systems }\end{array}$ & $\begin{array}{l}\text { Gastrointestinal issues, liver } \\
\text { and kidney damage }\end{array}$ & 1.3 & 2.0 & [40-42] \\
\hline Lead $(\mathrm{Pb})$ & $\begin{array}{l}\text { Lead-based } \\
\text { product, } \\
\text { household } \\
\text { plumbing systems }\end{array}$ & Reduced neural development & 0.0 & 0.01 & [43-46] \\
\hline Mercury $(\mathrm{Hg})$ & $\begin{array}{l}\text { Fossil fuel } \\
\text { combustion, } \\
\text { electronic } \\
\text { industries }\end{array}$ & $\begin{array}{l}\text { Kidney damage, nervous } \\
\text { system damage }\end{array}$ & 0.002 & 0.006 & [47-49] \\
\hline
\end{tabular}

The adsorption process has been measured as the most suitable technique for removing heavy metals from the water stream. It can remove pollutants even at the lowest metal ion concentrations. In addition, this process also requires low energy consumption and has many types of raw materials to act as the adsorbent $[6,42,50,51]$. Theoretically, as presented in Figure 1 , the adsorption process involves the attachment of the adsorbate (metal ion) to the active adsorbent site. The process of adsorption can occur in two types which are physisorption and chemisorption. In physisorption, the adsorption process takes place between the adsorbent and adsorbate via van der Waals forces. Meanwhile, the chemisorption process occurs when adsorbates are chemically attached to the active site of the adsorbent. The capability of the adsorption process is measured by the ability of the adsorbent to adsorb the heavy metals that can be identified through the adsorption capacity. In addition, the aspects influencing the adsorption capacity include the type of the pollutant, solution $\mathrm{pH}$, duration time between the adsorbate and adsorbent, initial concentration of the metal ions, surface charge, surface area, type of active sites groups of adsorbents as well as the molecular size of the heavy metals.

\section{Adsorbate}

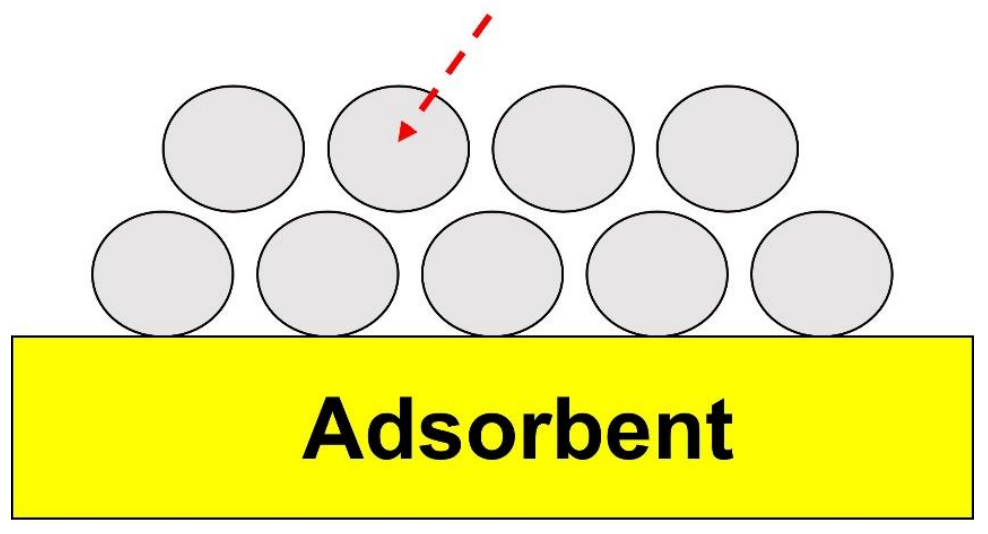

Figure 1. The attachment process of the adsorbate and the adsorbent. 


\subsection{Adsorption parameters.}

The adsorption capacity of heavy metals onto adsorbents depends on several parameters, including the initial concentration of heavy metals, solution $\mathrm{pH}$, average contact time, adsorbent dosage, etc. Several parameters that influence the performance of adsorption of heavy metal ions to carbon adsorbent are discussed. The $\mathrm{pH}$ of the solution is very significant as it will affect the adsorption process and the absorbent surface charge. As studied by Zhan and the group, the adsorption performance of the $\mathrm{Cu}$ (II) and $\mathrm{Pb}$ (II) onto CNTs-GO aerogels was obviously increased starting from the $\mathrm{pH} 2$ to 7 from $67 \mathrm{mg} / \mathrm{g}$ and $95 \mathrm{mg} / \mathrm{g}$ to $224 \mathrm{mg} / \mathrm{g}$ and $271 \mathrm{mg} / \mathrm{g}$, respectively [52]. Zeta potential at different $\mathrm{pH}$ values was measured. From the results, it was found that the zeta potential for both CNTs and GO started to decrease as the solution $\mathrm{pH}$ increased from $\mathrm{pH} 2$ to $\mathrm{pH}$ 7. At lower $\mathrm{pH}$, the high concentration of $\mathrm{H}+$ ions began to compete with the $\mathrm{Cu}$ (II) and $\mathrm{Pb}$ (II) ions to be mounted on a negatively charged GO surface. Therefore, it will produce a virtual repulsion of metal ions. Meanwhile, when the $\mathrm{pH}$ starts to rise to $\mathrm{pH} 7$, there is minimal competition between $\mathrm{Cu}$ (II) and $\mathrm{Pb}$ (II) with $\mathrm{GO}$, resulting in better adsorption capacity. In addition to the $\mathrm{pH}$ of the solution, the initial concentration of heavy metal ions also played a significant role in the adsorption performance. Theoretically, as the initial concentration of heavy metal ions increases, the collision between the metal ions and the active surface of the adsorbent increases. In line with this, the adsorption capacity will increase.

In addition, the duration of the contact time is one of the crucial parameters because it is necessary to attain the equilibrium for the adsorption of the heavy metal to the surface of the adsorbent. Normally, as the contact time increases, the interaction between the adsorbent and adsorbate will increase until it reaches the equilibrium point, which means that the surface of the adsorbent itself is already saturated with the metal ion. The contact time will influence the life span of the adsorbent and also the adsorption time efficiency. A longer contact time will increase the adsorption capacity since the duration for the adsorbate to be adsorbed onto the active site of the adsorbent is longer. The presence of the available active sites will accelerate the attachment of the metal ions to be penetrated onto the adsorbent. The equilibrium point of the adsorption process is achieved when all available active sites are fully absorbed by the metal ions. At this point, no adsorption occurs because the rate of adsorption and absorption are the same. As elaborated by Sadeghi and the group, the adsorption time of $\mathrm{Hg}(\mathrm{II})$ and $\mathrm{As}(\mathrm{V})$ onto the synthesized GO reached 12 minutes [53]. From these observations, it is found that the adsorption process shows rapid initial adsorption for the first 2 minutes. This situation indicates that there is rapid diffusion of metal ions to the GO surface. After 12 minutes, the adsorption capacity for $\mathrm{Hg}(\mathrm{II})$ and $\mathrm{As}(\mathrm{V})$ reached $7.95 \mathrm{mg} / \mathrm{g}$ and $51.43 \mathrm{mg} / \mathrm{g}$, respectively.

\subsection{Adsorption and kinetic isotherms.}

The adsorption capacity of heavy metals onto adsorbents depends on several parameters, including the initial concentration of heavy metals, solution $\mathrm{pH}$, average contact time, adsorbent dosage, etc. Several parameters that influence the performance of adsorption of heavy metal ions to carbon adsorbent are discussed. The $\mathrm{pH}$ of the solution is very significant as it will affect the adsorption process and the absorbent surface charge. As studied by Zhan and the group, the adsorption performance of the $\mathrm{Cu}$ (II) and $\mathrm{Pb}$ (II) onto CNTs-GO aerogels was obviously increased starting from the $\mathrm{pH} 2$ to 7 from $67 \mathrm{mg} / \mathrm{g}$ and $95 \mathrm{mg} / \mathrm{g}$ to $224 \mathrm{mg} / \mathrm{g}$ and $271 \mathrm{mg} / \mathrm{g}$, respectively [52]. Zeta potential at different $\mathrm{pH}$ values was measured. From the 
results, it was found that the zeta potential for both CNTs and GO started to decrease as the solution $\mathrm{pH}$ increased from $\mathrm{pH} 2$ to $\mathrm{pH}$ 7. At lower $\mathrm{pH}$, the high concentration of $\mathrm{H}+$ ions began to compete with the $\mathrm{Cu}$ (II) and $\mathrm{Pb}$ (II) ions to be mounted on a negatively charged GO surface. Therefore, it will produce a virtual repulsion of metal ions. Meanwhile, when the $\mathrm{pH}$ starts to rise to $\mathrm{pH} 7$, there is minimal competition between $\mathrm{Cu}$ (II) and $\mathrm{Pb}$ (II) with GO, resulting in better adsorption capacity. In addition to the $\mathrm{pH}$ of the solution, the initial concentration of heavy metal ions also played a significant role in the adsorption performance. Theoretically, as the initial concentration of heavy metal ions increases, the collision between the metal ions and the active surface of the adsorbent increases. In line with this, the adsorption capacity will increase.

The purpose of the adsorption isotherm study is to analyze the adsorption behavior of the adsorbate to the adsorbent surface in terms of heavy metal concentration. This study will show the effect of the initial concentration of metal ions and the number of ions to be absorbed at equilibrium. The equilibrium between the amount of the metal ions adsorbed and the amount of the total ions remains in the solution reached as the mass of the adsorbent has a sufficient contact time with the metal ions. The adsorption isotherms model is applicable for batch adsorption studies by varying the initial concentration of the heavy metals. Commonly, there are two types of isotherms models that are presented to determine the behavior and the mechanism of the adsorption process. Langmuir and Freundlich's models are employed to fit the experimental adsorption value. These models are useful to measure the maximum adsorption capacity of the adsorbate by the adsorbent [26,54]. Table 2 compares the models in terms of equations, parameters, and the elaboration of the Langmuir and Freundlich models.

The contact time between the adsorbent and the metal ions is vital to reaching the optimum removal of the heavy metals from the aqueous solutions. The kinetic studies refer to the reaction route for the time of the adsorption process to reach equilibrium. This study will show the amount of time it takes to achieve the optimum adsorption process. To clarify the adsorption mechanism process, the data were tested using two general models: pseudo-first and pseudo-second models. High correlation coefficients, $\mathrm{R}^{2}$ value indicates that the model successfully expresses the kinetics of the adsorption process. Table 3 explains the types of isotherm models, including the related equations and the brief descriptions of the pseudo-first and pseudo-second models, respectively.

Table 2. Linear formula equations, parameters, and descriptions of the adsorption isotherm models.

\begin{tabular}{|c|c|c|c|c|}
\hline Isotherms & Linear form & Parameters & Description & Ref. \\
\hline Langmuir & $\frac{\mathrm{Ce}}{\mathrm{qe}}=\frac{1}{\mathrm{qmKL}} \mathrm{Ce}+\frac{1}{\mathrm{KLqm}}$ & $\begin{array}{l}\mathrm{C}_{\mathrm{e}}(\mathrm{mg} / \mathrm{L}) \text { : } \\
\text { Concentration of metal ions } \\
\text { at equilibrium. } \\
\mathrm{q}_{\mathrm{e}}(\mathrm{mg} / \mathrm{g}) \text { : } \\
\text { The amount of adsorbate } \\
\text { adsorbed at equilibrium. } \\
\mathrm{K}_{\mathrm{L}}(\mathrm{L} / \mathrm{mg}) \text { : } \\
\text { Langmuir constant. } \\
\mathrm{q}_{\mathrm{m}}(\mathrm{mg} / \mathrm{g}) \text { : } \\
\text { Maximum } \\
\text { capacity. }\end{array}$ & $\begin{array}{l}\text { - Refer to the monolayer } \\
\text { adsorption process. } \\
\text { - The affinity and the } \\
\text { favorableness between the } \\
\text { adsorbent and the adsorbate } \\
\text { also can be predicted by } \\
\text { using Langmuir constant } \\
\text { KL from the dimensionless } \\
\text { constant separation factor, } \\
\text { RL. } \\
\mathrm{R}_{\mathrm{L}}=\left(1 / 1+\mathrm{K}_{\mathrm{L}} \mathrm{C}_{0}\right) \\
\mathrm{Where} \\
\mathrm{C}_{0} \text { : } \\
\text { Initial concentration of } \\
\text { adsorbate }(\mathrm{mg} / \mathrm{L})\end{array}$ & {$[26,55,56]$} \\
\hline
\end{tabular}




\begin{tabular}{|c|c|c|c|c|}
\hline Isotherms & Linear form & Parameters & Description & Ref. \\
\hline & & & $\begin{array}{l}\text { 1)Irreversible }\left(\mathrm{R}_{\mathrm{L}}=0\right) \\
\text { 2)Favorable }\left(0<\mathrm{R}_{\mathrm{L}}<1\right) \\
\text { 3)Linear }\left(\mathrm{R}_{\mathrm{L}}=1\right) \\
\text { 4)Unfavorable }\left(\mathrm{R}_{\mathrm{L}}>1\right)\end{array}$ & \\
\hline Freundlich & $\ln \mathrm{qe}=\ln \mathrm{Kf}+\frac{1}{\mathrm{n}} \ln \mathrm{Ce}$ & $\begin{array}{l}\mathrm{q}_{\mathrm{e}}(\mathrm{mg} / \mathrm{g}) ; \\
\text { Adsorption capacity of } \\
\text { metal ions adsorbed at } \\
\text { equilibrium. } \\
\mathrm{C}_{\mathrm{e}}(\mathrm{mg} / \mathrm{L}) \text {; } \\
\text { metal ions at equilibrium } \\
1 / \mathrm{n} \text {; } \\
\text { heterogeneity } \\
\text { (dimensionless) } \\
\mathrm{K}_{\mathrm{f}}(\mathrm{L} / \mathrm{g}) ; \\
\text { Freundlich actor } \\
\text { constant adsorption }\end{array}$ & $\begin{array}{l}\text { - Adsorption based on the } \\
\text { heterogeneous surface. } \\
\text { - Applied to multilayer } \\
\text { adsorption. } \\
\text { - } 1 / \mathrm{n} \text { refers to the } \\
\text { heterogeneity of the } \\
\text { adsorbent surface. } \\
\text { - The value of } 1 / \mathrm{n} \text { signified } \\
\text { the indication of the } \\
\text { favorability of adsorption. } \\
\text { i) Irreversible }(1 / \mathrm{n}=0) \\
\text { ii) Favorable } \\
(0<1 / \mathrm{n}<1) \\
\text { iii)Unfavorable } \\
(1 / \mathrm{n}>1)\end{array}$ & {$[26,54,57]$} \\
\hline
\end{tabular}

Table 3. Linear formula equations, parameters and descriptions of the adsorption kinetic models.

\begin{tabular}{|c|c|c|c|c|}
\hline Isotherms & Expression of formula & Parameters & Description & Ref. \\
\hline $\begin{array}{l}\text { Pseudo- } \\
\text { first order } \\
\text { model }\end{array}$ & $\frac{d q t}{d t}=\mathrm{k}_{1}\left(\mathrm{q}_{\mathrm{e}}-\mathrm{q}_{\mathrm{t}}\right)$ & $\begin{array}{l}\mathrm{q}_{\mathrm{e}}(\mathrm{mg} / \mathrm{g}) ; \quad \text { Equilibrium } \\
\text { adsorption capacity } \\
\mathrm{q}_{\mathrm{t}}(\mathrm{mg} / \mathrm{g}) ; \\
\text { Adsorption capacity at time, } \mathrm{t} \\
\mathrm{t}(\mathrm{min}) ; \\
\text { contact time } \\
\mathrm{k}_{1}\left(\mathrm{~min}^{-1}\right) ; \\
\text { rate constant of pseudo-first } \\
\text { order }\end{array}$ & $\begin{array}{l}\text { - Physisorption. } \\
\text { - The target molecules } \\
\text { attached via Van der } \\
\text { Waals forces. } \\
\text { - Low heat of adsorption. }\end{array}$ & {$[57-60]$} \\
\hline $\begin{array}{l}\text { Pseudo- } \\
\text { second } \\
\text { model }\end{array}$ & $\frac{d q t}{d t}=\mathrm{k}_{2}\left(\mathrm{q}_{\mathrm{e}}-\mathrm{q}_{\mathrm{t}}\right)^{2}$ & $\begin{array}{l}\mathrm{q}_{\mathrm{e}}(\mathrm{mg} / \mathrm{g}) ; \\
\text { equilibrium } \\
\text { capacity } \\
\mathrm{q}_{\mathrm{t}}(\mathrm{mg} / \mathrm{g}) ; \\
\text { Adsorption capacity at time, } \mathrm{t} \\
\mathrm{t}(\mathrm{min}) ; \\
\text { contact time } \\
\mathrm{k}_{2}\left(\mathrm{~min}^{-1}\right) \text {; } \\
\text { rate constant of pseudo-second } \\
\text { order }\end{array}$ & $\begin{array}{l}\text { - Indicate chemical } \\
\text { adsorption or known as } \\
\text { chemisorptions. } \\
\text { - Covalent bonding } \\
\text { between metal ions and } \\
\text { adsorbent. }\end{array}$ & {$[25,61,62]$} \\
\hline
\end{tabular}

\section{Carbon-based Materials (Mauro)}

Carbon-based materials have excellent properties because they can be chemically bonded to many other types of carbon materials through strong covalent bonds. Because of these characteristics, they have excellent and superior materials in terms of hardness, density, and strength. In order to increase the capability of the adsorptive behavior, the surface functional groups can be altered. This process may involve the post-treatment process of carbon materials with chemical agents to obtain the appropriate carbon materials to act as the adsorbent. There are three types of modifications that have been proposed, namely oxidation, nitrogenation, and sulfurization. All of these techniques will introduce oxygen, nitrogen, and 
sulfur to the carbon surface to create an active functional group [63]. As a comparison of the three techniques mentioned, surface oxidation is the most conventional and simplest modification.

In particular, AC, CNTs, and graphene oxide $(\mathrm{GO})$ are the most widely used materials in adsorption for heavy metal removal. Their adsorption performance has been extensively studied [64-66]. Among all the listed materials, AC is highlighted as the most used material as the adsorbent $[67,68]$. The porous structure of the $\mathrm{AC}$ can be altered by changing the activation parameters, including the types of the activation, either physical or chemical, activating agents, pyrolysis temperature, and impregnation ratio. In addition, the type of the activating agent is important in order to ensure the type of the active groups at the adsorbent's surface. The preparation of the AC can be grouped into physical and chemical activation [69-71]. Physical activation has two major steps, which are the pyrolysis and activation step. In the first step, the carbon precursor undergoes a pyrolysis process at low temperatures without any air. The char obtained then undergoes an activation step under an oxidizing condition to increase its surface area. Increasing the surface area will improve the porosity, thus improving the removal of the metal ions during the adsorption process.

Chemical activation is a one-step process by which carbon precursors are immersed in dehydration agents such as potassium hydroxide. The process is performed under high temperatures in an inert atmosphere. In comparison, chemical activation is preferred because it offers several advantages, such as low activation temperature, minimal heat treatment, and high carbon content $[69,72]$. However, it is worth mentioning that operating under an oxidizing environment is better than an inert atmosphere condition since the porosity of the AC will be improved. In addition, the use of airflow during the process will increase the AC surface's oxygen content and increase the surface area of the carbon pore structure [69]. In another approach, AC is made from rare materials such as chicken feathers and eggshells[70]. Both of the materials undergo acid digestion to turn into $\mathrm{AC}$ before being modified by the addition of magnetic iron to adsorb $\mathrm{Pb}(\mathrm{II}), \mathrm{Cu}(\mathrm{II}), \mathrm{Zn}(\mathrm{II}), \mathrm{Cd}(\mathrm{II})$, and $\mathrm{Ni}(\mathrm{II})$.

The advancement of nanotechnology has created graphene-based materials, including graphene (GR) and CNTs as the adsorbent $[22,51,73,74]$. GR is one of the most popular carbonbased materials recently used as an absorbent to remove metal ions [22,53,75-79]. GO is the oxidized form of GR that is produced from the chemical or thermal reaction process. GO has a high surface area which is preferable in heavy metal removal applications. As mentioned by Yao et al., the GO nanosheets possess higher sorption capacity than CNTs as they consist of large numbers of oxygen molecules [79]. In addition, the chemical synthesis of GO via Hummers methods is simple, thus making it easier to be produced. The multiples sheet of the rolled GO will produce cylindrical carbon tubes. As stated by Zhan et al., GO has been identified as one of the most popular materials in heavy metal removal due to many available negatively charged sites [52]. The nature of the GO is likely to restack or agglomerate due to the van der Waals interaction and $\pi-\pi$ stacking, which can use up a large number of active sites. However, the GO sheet is still dispersing in water due to the presence of oxygen molecules in its structure. The CNTs are made up of countless carbon chains. A single carbon atom is attached to three carbon atoms, which will form a carbon hybrid of $\mathrm{sp}^{2}$. The hybridization of $\mathrm{sp}^{2}$ is greater compared to $\mathrm{sp}^{3}$ found in the diamond. Thus, it shows atypical strength with excellent thermal and electrical conductivity. As presented in Figure 2, CNTs can be categorized into two types of groups: Multiwall CNTs (MWCNTs) consisting of multilayer GR sheets and single-wall CNTs (SWCNTs) with single-sheet GR sheets. Referring to Figure 
3, to form a nanotube, the vector length of the GR sheet needs to be measured equally[80]. Based on Figure 3 (b-d), SWCNTs can be divided into three classes, namely zig-zag, chiral, and armchair. The differences between classes are distinguished by the direction of the vector GR sheet.

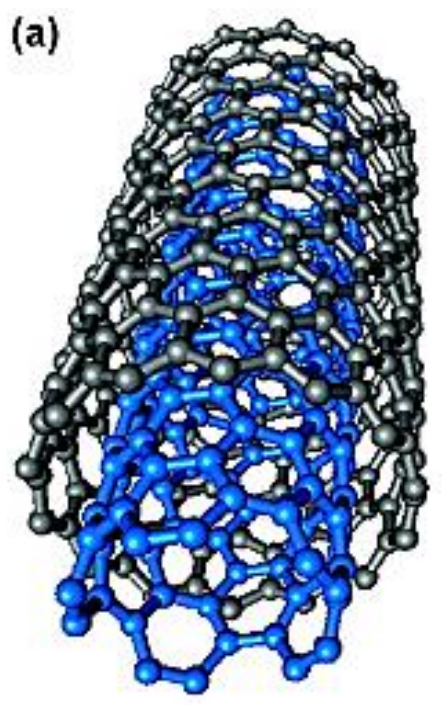

(b)

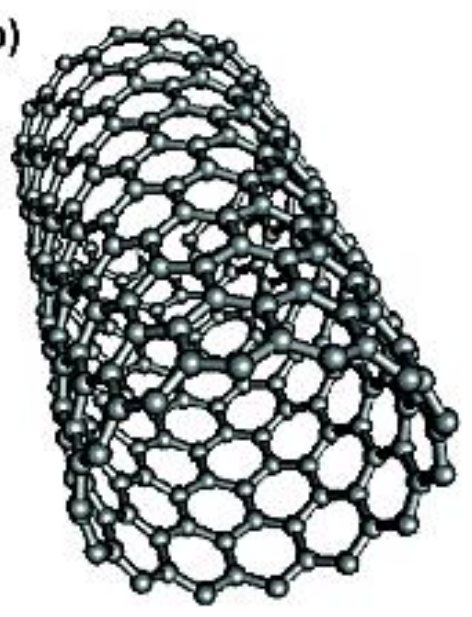

Figure 2. The structures of (a) MWCNTs and (b) SWCNTs. Reprinted with permission from [81]. Copyright 2009 American Chemical Society.

(a)

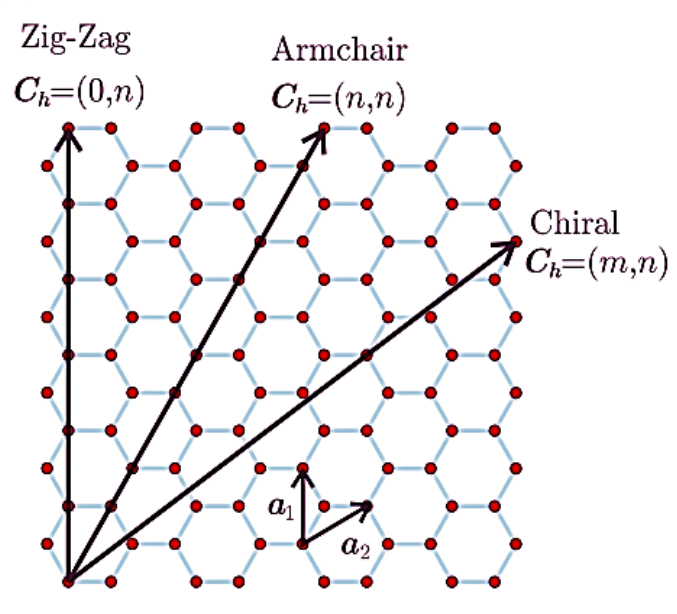

(b)

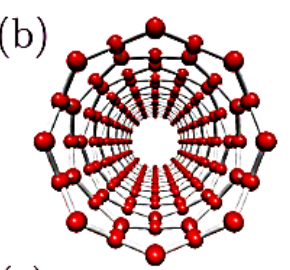

(c)

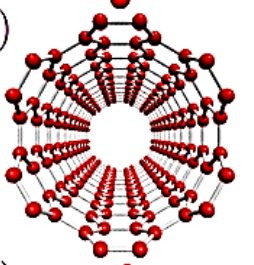

(d)

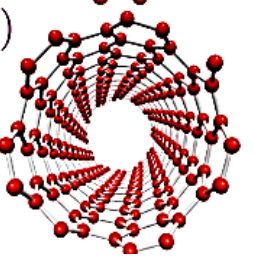

Figure 3. (a) The vectors of the GR sheets; (b)zig-zag; (c) armchair; (d) chiral of SWCNTs [80].

In removing various metal ions in water, CNTs are commonly used due to their large surface area, high porous structure, and strong chemical interaction with metal ions. [63,74]. The adsorption behavior of metal ions onto the CNTs surface is majorly dependent on the purity, porosity, active groups, surface area, and the types of the CNTs, either open closeended. As presented in Figure 4, there are four possible CNTs main sites that are believed to function as adsorption sites which are (1) internal sites, (2) interstitial channels (ICs), (3) grooves, and (4) outer surface [82]. As Ihsanullah and the group mentioned, most of the adsorption will occur at the ICs, outer surface, and grooves sites [31]. Most of the adsorption at the ICs and grooves involved the adsorption of methane $\left(\mathrm{CH}_{4}\right)$ and krypton $(\mathrm{Kr})$. Meanwhile, the grooves are able to adsorb larger molecules such as xenon $(\mathrm{Xe})$, simplest fluorocarbon $\left(\mathrm{CF}_{4}\right)$, and sulfur hexafluoride $\left(\mathrm{SF}_{6}\right)$. In addition, the adsorption processes on the CNTs are also 
influenced by the amount of open and unobstructed nanotubes. Opening the end of the CNTs will increase the number of adsorption sites, thereby increasing the adsorption process's saturation capability and kinetic rate. The adsorption performance of metal ions measured via adsorption capacity of the acid-modified CNTs is higher in almost all the studies [83-85]. This situation may be associated with the electrostatic interaction between the negative charge on the CNTs and the positive charge of the metal ions.

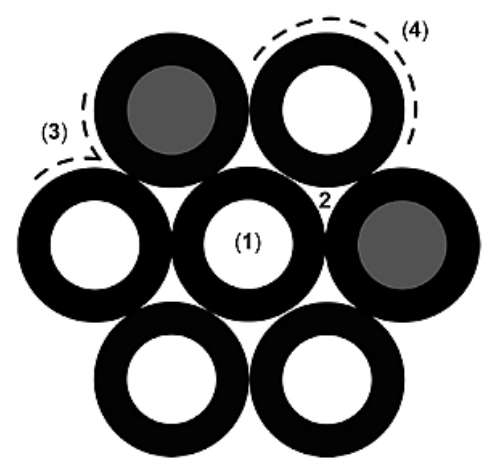

Figure 4. Possible CNTs main sites that are believed to function as adsorption sites. Reprinted (adapted) with permission from [82]. Copyright 2006 American Chemical Society.

\subsection{Mechanism of heavy metal removal by carbon-based materials.}

Generally, the intermolecular interactions between the active site of the adsorbent and metal ions are complex. Specifically, the interaction highly depends on active groups on the carbon surface, the environment of the heavy metal ions solution, and the type of the adsorbate, either positive or negative charge. The adsorption mechanism of metal ions on the carbon surface can be divided into five main types: electrostatic interaction, surface complexation, ion exchange, precipitation, and physical adsorption [33,63,71]. Each type of mechanism acts for different adsorption processes based on the type of metal ions, the $\mathrm{pH}$ of the solution, and the nature of the carbon adsorbent. In particular, ion exchange, surface complexation, and precipitation are categorized as chemisorption. Meanwhile, electrostatic interaction and physical adsorption are related to the physisorption interaction. Hadi and the group stated that the chemisorption mechanism is majorly linked to the surface functional groups via electrostatic force, the creation of the binding site, and the covalent bonding form between adsorbate and the active groups of the carbon surfaces [69].

Surface complexation will form complex structures with unique metal functional groups interactions. The metal ions can form complexation with carboxyl and phenolic functional groups [47,86]. As studied by Zbair et al. the removal of the $\mathrm{Cr}(\mathrm{III}), \mathrm{Pb}(\mathrm{II}), \mathrm{Cd}(\mathrm{II})$, and $\mathrm{Cu}(\mathrm{II})$ is improved because of the electrostatic interaction between the metal ions and carbon microspheres [87]. Hou and his team also emphasize that the removal of $\mathrm{Cd}(\mathrm{II}), \mathrm{Pb}$ (II), and $\mathrm{Cu}(\mathrm{II})$ is enhanced by electrostatic interactions created through negatively charged surfaces of magnetic layered double oxide/carbon $(\mathrm{Mag} / \mathrm{LDO} / \mathrm{C})$ with positively charged of the metal ions [56]. The influence of similar mechanisms was also observed for the removal of Cd(II), $\mathrm{Cu}(\mathrm{II})$, and $\mathrm{Zn}$ (II) [67,88]. In another approach, the removal of the $\mathrm{Zn}$ (II), $\mathrm{Cd}(\mathrm{II}), \mathrm{Cu}(\mathrm{II}), \mathrm{Ni}(\mathrm{II})$, and $\mathrm{Pb}$ (II) by carbon material (CNM) synthesized from charcoal cross-linked with hyperbranched polyethyleneimine (HPEI) is improved due to the steric hindrance and Donnan electrostatic exclusion [89]. 


\begin{tabular}{|c|c|c|c|c|c|c|}
\hline Adsorbents & Modification & Adsorbates & Optimal conditions & $\begin{array}{l}\text { Adsorption capacity }(\mathrm{mg} / \mathrm{g}) / \\
\text { Adsorption removal }(\%)\end{array}$ & Kinetic/ adsorption model & Ref. \\
\hline CNTs-GO & $\begin{array}{l}\text { Amino functionalized CNTs- } \\
\text { GO aerogels }\end{array}$ & $\begin{array}{l}\mathrm{Pb}(\mathrm{II}) \\
\mathrm{Cu}(\mathrm{II})\end{array}$ & $\begin{array}{l}\mathrm{pH}=7, \\
{[\text { conc.] }=400 \mathrm{mg} / \mathrm{L}} \\
\mathrm{T}=60 \mathrm{~min}\end{array}$ & $\begin{array}{l}350.87 \mathrm{mg} / \mathrm{g} \\
318.47 \mathrm{mg} / \mathrm{g}\end{array}$ & Pseudo-second order/Langmuir & [52] \\
\hline $\mathrm{AC}$ & $\begin{array}{l}\text { Iron magnetized eggshell } \\
\text { activated chicken feather } \\
\text { carbon (IOM-ESCFC) }\end{array}$ & $\begin{array}{l}\mathrm{Pb}(\mathrm{II}) \\
\mathrm{Cd}(\mathrm{II}) \\
\mathrm{Cu}(\mathrm{II}) \\
\mathrm{Zn}(\mathrm{II}) \\
\mathrm{Ni}(\mathrm{II})\end{array}$ & $\begin{array}{l}\mathrm{pH}=5.5 \\
{[\text { conc.] }=25 \mathrm{mg} / \mathrm{g}} \\
\mathrm{T}=60 \mathrm{~min}\end{array}$ & $\begin{array}{l}96.1 \mathrm{mg} / \mathrm{g} \\
93.8 \mathrm{mg} / \mathrm{g} \\
83.3 \mathrm{mg} / \mathrm{g} \\
69.6 \mathrm{mg} / \mathrm{g} \\
50 \%\end{array}$ & Pseudo-second order/Langmuir & [70] \\
\hline $\mathrm{AC}$ & $\begin{array}{l}\text { Honeydew peel AC treated } \\
\text { with } \mathrm{H}_{2} \mathrm{SO}_{4}(\mathrm{HDP}-\mathrm{ACS}) \text { and } \\
\mathrm{H}_{3} \mathrm{PO}_{4}(\mathrm{HDP}-\mathrm{ACP})\end{array}$ & $\begin{array}{l}\text { Cr(II)-HDP-ACS } \\
\text { Zn(II)- HDP-ACS } \\
\text { Cr(II)-HDP-ACP } \\
\text { Zn(II)- HDP-ACP }\end{array}$ & $\begin{array}{l}\mathrm{pH}=4.5 \\
{[\text { conc. }]=1000 \mathrm{mg} / \mathrm{L}} \\
\mathrm{T}=40 \mathrm{~min} \\
\mathrm{pH}=5.5 \\
{[\text { conc. }]=400 \mathrm{mg} / \mathrm{L}} \\
\mathrm{T}=40 \mathrm{~min} \\
\mathrm{pH}=4.5 \\
{[\text { conc. }]=1000 \mathrm{mg} / \mathrm{L}} \\
\mathrm{T}=40 \mathrm{~min} \\
\mathrm{pH}=5.5 \\
{[\text { conc. }]=400 \mathrm{mg} / \mathrm{L}} \\
\mathrm{T}=40 \mathrm{~min}\end{array}$ & $\begin{array}{l}834.94 \mathrm{mg} / \mathrm{g} \\
326.19 \mathrm{mg} / \mathrm{g} \\
888.85 \mathrm{mg} / \mathrm{g} \\
336.51 \mathrm{mg} / \mathrm{g}\end{array}$ & NA & [94] \\
\hline GO & $\begin{array}{l}\text { Synthesized GO via unzipping } \\
\text { of MWCNTs }\end{array}$ & $\begin{array}{l}\mathrm{As}(\mathrm{V}) \\
\mathrm{Hg}(\mathrm{II})\end{array}$ & $\begin{array}{l}\mathrm{pH}=5.5 \\
{[\text { conc.] }==300 \mathrm{mg} / \mathrm{L}} \\
\mathrm{T}=12 \mathrm{~min}\end{array}$ & $\begin{array}{l}155.61 \mathrm{mg} / \mathrm{g} \\
33.02 \mathrm{mg} / \mathrm{g}\end{array}$ & $\begin{array}{l}\text { Pseudo-second order /Freundlich } \\
\text { Pseudo-first order/ Freundlich }\end{array}$ & [53] \\
\hline $\mathrm{AC}$ & $\begin{array}{l}\text { AC synthesized from Elm tree } \\
\text { waste via thermal tension } \\
\text { treated }\end{array}$ & $\begin{array}{l}\mathrm{Pb}(\mathrm{II}) \\
\mathrm{Cr}(\mathrm{VI})\end{array}$ & $\begin{array}{l}\mathrm{pH}=5 \\
{[\text { conc. }]=50 \mathrm{mg} / \mathrm{L}} \\
\mathrm{T}=60 \mathrm{~min} \\
\mathrm{pH}=2 \\
{[\text { conc. }]==50 \mathrm{mg} / \mathrm{L}} \\
\text { contact time }=60 \mathrm{~min}\end{array}$ & $232.56 \mathrm{mg} / \mathrm{g}$ & $\begin{array}{l}\text { Pseudo-second order/Langmuir } \\
\text { Pseudo-second order/Langmuir }\end{array}$ & [95] \\
\hline $\mathrm{AC}$ & $\begin{array}{l}\text { Synthesized AC from rayon } \\
\text { fiber via physical activation }\end{array}$ & $\begin{array}{l}\mathrm{Cu}(\mathrm{II}) \\
\mathrm{Pb}(\mathrm{II})\end{array}$ & $\begin{array}{l}\text { [conc.] }=20 \mathrm{mg} / \mathrm{L} \\
\mathrm{T}=48 \mathrm{~h} \\
{[\text { conc. }]=40 \mathrm{mg} / \mathrm{L}} \\
\mathrm{T}=48 \mathrm{~h}\end{array}$ & $\begin{array}{l}50 \% \\
75 \%\end{array}$ & NA & [71] \\
\hline
\end{tabular}




\begin{tabular}{|c|c|c|c|c|c|c|}
\hline Adsorbents & Modification & Adsorbates & Optimal conditions & $\begin{array}{l}\text { Adsorption capacity }(\mathrm{mg} / \mathrm{g}) / \\
\text { Adsorption removal }(\%)\end{array}$ & Kinetic/ adsorption model & Ref. \\
\hline CNTs & $\begin{array}{l}\text { Functionalized silica-coated } \\
\text { magnetic MWCNTs }\end{array}$ & $\begin{array}{l}\mathrm{Pb}(\mathrm{II}) \\
\mathrm{Cd}(\mathrm{II})\end{array}$ & $\begin{array}{l}\text { [conc. }]=10 \mathrm{mg} / \mathrm{L} \\
\mathrm{T}=5 \mathrm{~min}\end{array}$ & $\begin{array}{l}89 \mathrm{mg} / \mathrm{g} \\
94.5 \mathrm{mg} / \mathrm{g}\end{array}$ & NA & [96] \\
\hline $\mathrm{AC}$ & $\begin{array}{l}\text { Sewage sludge derived } \\
\text { carbon-supported } \mathrm{MgO} \\
\text { composite }\end{array}$ & $\begin{array}{l}\mathrm{Pb}(\mathrm{II}) \\
\mathrm{Cd}(\mathrm{II})\end{array}$ & $\begin{array}{l}\mathrm{pH}=5 \\
\text { [conc.] }=200 \mathrm{mg} / \mathrm{L} \\
\mathrm{T}=180 \mathrm{~min} \\
\mathrm{pH}=6 \\
{[\text { conc.] }=200 \mathrm{mg} / \mathrm{L}} \\
\mathrm{T}=180 \mathrm{~min}\end{array}$ & $\begin{array}{l}2391.76 \mathrm{mg} / \mathrm{g} \\
861.11 \mathrm{mg} / \mathrm{g}\end{array}$ & Pseudo-second model/Redlich-Peterson & [90] \\
\hline $\mathrm{AC}$ & $\begin{array}{l}\text { multi-pore acivated carbons } \\
\text { (MPAC) from long-root } \\
\text { Eichhornia crassipes }\end{array}$ & $\begin{array}{l}\mathrm{Pb}(\mathrm{II}) \\
\mathrm{Cd}(\mathrm{II}) \\
\mathrm{Cu}(\mathrm{II}) \\
\mathrm{Zn}(\mathrm{II}) \\
\mathrm{Ni}(\mathrm{II})\end{array}$ & $\begin{array}{l}\mathrm{pH}=6 \\
{[\text { conc.] }=1 \mathrm{mmol} / \mathrm{L}} \\
\mathrm{T}=240 \mathrm{~min}\end{array}$ & $\begin{array}{l}277.6 \mathrm{mg} / \mathrm{g} \\
67.9 \mathrm{mg} / \mathrm{g} \\
137.1 \mathrm{mg} / \mathrm{g} \\
56.9 \mathrm{mg} / \mathrm{g} \\
61.9 \mathrm{mg} / \mathrm{g}\end{array}$ & Pseudo-second model /Langmuir & [97] \\
\hline CNTs & Iron oxide filled MWCNTs & $\begin{array}{l}\mathrm{Cr}(\mathrm{VI}) \\
\mathrm{Fe}(\mathrm{II}) \\
\mathrm{Pb}(\mathrm{II}) \\
\mathrm{Cu}(\mathrm{II})\end{array}$ & $\begin{array}{l}\mathrm{pH}=6 \\
{[\text { conc. }]=100 \mathrm{mg} / \mathrm{L}} \\
\mathrm{T}=30 \mathrm{~min}\end{array}$ & $\begin{array}{l}39.31 \% \\
35.53 \% \\
34.48 \% \\
29.63 \%\end{array}$ & NA & [93] \\
\hline $\mathrm{AC}$ & Egg white derived AC & $\mathrm{Co}(\mathrm{III})$ & $\begin{array}{l}\mathrm{pH}=6 \\
{[\text { conc.] }=100 \mathrm{mg} / \mathrm{L}} \\
\mathrm{T}=240 \mathrm{~min}\end{array}$ & $320.3 \mathrm{mg} / \mathrm{g}$ & Pseudo-second order/Langmuir & [98] \\
\hline $\mathrm{AC}$ & $\begin{array}{l}\text { Carbon microsphere from } \\
\text { walnut shell }\end{array}$ & $\begin{array}{l}\mathrm{Cr}(\mathrm{III}) \\
\mathrm{Pb}(\mathrm{II}) \\
\mathrm{Cd}(\mathrm{II}) \\
\mathrm{Cu}(\mathrm{II})\end{array}$ & $\begin{array}{l}\mathrm{pH}=5 \\
{[\text { conc.] }=50 \mathrm{mg} / \mathrm{L}} \\
\mathrm{T}=300 \mathrm{~min}\end{array}$ & $\begin{array}{l}792 \mathrm{mg} / \mathrm{g} \\
638 \mathrm{mg} / \mathrm{g} \\
574 \mathrm{mg} / \mathrm{g} \\
345 \mathrm{mg} / \mathrm{g}\end{array}$ & Langmuir & [87] \\
\hline $\mathrm{AC}$ & Functionalized $\mathrm{AC}$ with $\mathrm{HNO}_{3}$ & $\begin{array}{l}\mathrm{Ni}(\mathrm{II}) \\
\mathrm{Co}(\mathrm{III})\end{array}$ & $\begin{array}{l}\mathrm{pH}=6 \\
\text { [conc.]=200 mg/L } \\
\mathrm{T}=24 \mathrm{~h}\end{array}$ & $\begin{array}{l}149.25 \mathrm{mg} / \mathrm{g} \\
140.85 \mathrm{mg} / \mathrm{g}\end{array}$ & Langmuir & [99] \\
\hline $\mathrm{AC}$ & $\begin{array}{l}\text { Magnetic layered double } \\
\text { oxide/carbon (Mag-LDO/C) }\end{array}$ & $\begin{array}{l}\mathrm{Cd}(\mathrm{II}) \\
\mathrm{Pb}(\mathrm{II})\end{array}$ & $\begin{array}{l}\mathrm{pH}=6 \\
{[\text { conc.] }=200 \mathrm{mg} / \mathrm{L}} \\
\mathrm{T}=90 \mathrm{~min} \\
\mathrm{pH}=6 \\
{[\text { conc. }]=400 \mathrm{mg} / \mathrm{L}} \\
\mathrm{T}=120 \mathrm{~min}\end{array}$ & $\begin{array}{l}386.1 \mathrm{mg} / \mathrm{g} \\
359.7 \mathrm{mg} / \mathrm{g}\end{array}$ & Pseudo-second order/Langmuir & [56] \\
\hline
\end{tabular}




\begin{tabular}{|c|c|c|c|c|c|c|}
\hline Adsorbents & Modification & Adsorbates & Optimal conditions & $\begin{array}{l}\text { Adsorption capacity }(\mathrm{mg} / \mathrm{g}) / \\
\text { Adsorption removal }(\%)\end{array}$ & Kinetic/ adsorption model & Ref. \\
\hline & & $\mathrm{Cu}(\mathrm{II})$ & $\begin{array}{l}\mathrm{pH}=6 \\
{[\text { conc.] }=200 \mathrm{mg} / \mathrm{L}} \\
\mathrm{T}=400 \mathrm{~min}\end{array}$ & $192.7 \mathrm{mg} / \mathrm{g}$ & & \\
\hline GO & $\begin{array}{l}\text { Chemically modified GO with } \\
\text { waste newspaper }\end{array}$ & $\begin{array}{l}\mathrm{Pb}(\mathrm{II}) \\
\mathrm{Ni}(\mathrm{II}) \\
\mathrm{Cd}(\mathrm{II})\end{array}$ & $\begin{array}{l}\mathrm{pH}=4 \\
{[\text { conc.] }=40 \mathrm{mg} / \mathrm{L}} \\
\mathrm{T}=12 \mathrm{~h}\end{array}$ & $\begin{array}{l}75.41 \mathrm{mg} / \mathrm{g} \\
29.04 \mathrm{mg} / \mathrm{g} \\
31.35 \mathrm{mg} / \mathrm{g}\end{array}$ & $\begin{array}{l}\text { Pseudo-second order/Langmuir } \\
\text { Pseudo-second order/Freundlich } \\
\text { Pseudo-second order/Freundlich }\end{array}$ & {$[100]$} \\
\hline GO & $\begin{array}{l}\text { Magnetized GO from natural } \\
\text { flake graphite }\end{array}$ & $\operatorname{Co}(\mathrm{II})$ & $\begin{array}{l}\mathrm{pH}=9 \\
{[\text { conc.] }=500 \mathrm{mg} / \mathrm{L}} \\
\mathrm{T}=5 \mathrm{~min}\end{array}$ & $379.2 \mathrm{mg} / \mathrm{g}$ & Pseudo-second order/Freundlich & {$[101]$} \\
\hline GO & $\begin{array}{l}\text { chemically modified GO by } \\
\text { bis(2-pyridylmethyl)amino } \\
\text { groups } \\
\text { (BPED) }\end{array}$ & $\begin{array}{l}\mathrm{Cu}(\mathrm{II}) \\
\mathrm{Ni}(\mathrm{II}) \\
\mathrm{Co}(\mathrm{II})\end{array}$ & $\begin{array}{l}\mathrm{pH}=7 \\
{[\text { conc.] }=250 \mathrm{mg} / \mathrm{L}} \\
\mathrm{T}=24 \mathrm{~h}\end{array}$ & $\begin{array}{l}3.464 \mathrm{mg} / \mathrm{g} \\
3.254 \mathrm{mg} / \mathrm{g} \\
3.054 \mathrm{mg} / \mathrm{g}\end{array}$ & Pseudo-second order & {$[58]$} \\
\hline GO & $\begin{array}{l}\text { Magnetized GO from } \\
\text { cellulose based graphite }\end{array}$ & $\mathrm{Cr}(\mathrm{VI})$ & $\begin{array}{l}\mathrm{pH}=2 \\
{[\text { conc.] }=10 \mathrm{mg} / \mathrm{L}} \\
\mathrm{T}=80 \mathrm{~min}\end{array}$ & $3.197 \mathrm{mg} / \mathrm{g}$ & Pseudo-second order/Langmuir & {$[102]$} \\
\hline GO & $\begin{array}{l}\text { Magnetized GO with with iron } \\
\text { particle }\end{array}$ & $\begin{array}{l}\mathrm{Pb}(\mathrm{II}) \\
\mathrm{Cr}(\mathrm{III}) \\
\mathrm{Cu}(\mathrm{II}) \\
\mathrm{Zn}(\mathrm{II})\end{array}$ & $\begin{array}{l}\mathrm{pH}=5 \\
{[\text { conc.] }=250 \mathrm{mg} / \mathrm{L}} \\
\mathrm{T}=25 \mathrm{~min} \\
\mathrm{pH}=6 \\
{[\text { conc.] }=250 \mathrm{mg} / \mathrm{L}} \\
\mathrm{T}=65 \mathrm{~min} \\
\mathrm{pH}=6 \\
{[\text { conc.] }==250 \mathrm{mg} / \mathrm{L}} \\
\mathrm{T}=25 \mathrm{~min} \\
\mathrm{pH}=7 \\
{[\text { conc. }]=250 \mathrm{mg} / \mathrm{L}}\end{array}$ & $\begin{array}{l}200 \mathrm{mg} / \mathrm{g} \\
24.33 \mathrm{mg} / \mathrm{g} \\
62.893 \mathrm{mg} / \mathrm{g} \\
63.694 \mathrm{mg} / \mathrm{g}\end{array}$ & $\begin{array}{l}\text { Pseudo-second order /Langmuir } \\
\text { Pseudo-second order /Langmuir } \\
\text { Pseudo-second order /Langmuir } \\
\text { Pseudo-second order /Langmuir }\end{array}$ & [103] \\
\hline
\end{tabular}




\begin{tabular}{|c|c|c|c|c|c|c|}
\hline Adsorbents & Modification & Adsorbates & Optimal conditions & $\begin{array}{l}\text { Adsorption capacity }(\mathrm{mg} / \mathrm{g}) / \\
\text { Adsorption removal }(\%)\end{array}$ & Kinetic/ adsorption model & Ref. \\
\hline & & $\mathrm{Ni}(\mathrm{II})$ & $\begin{array}{l}\mathrm{T}=35 \mathrm{~min} \\
\mathrm{pH}=8 \\
{[\text { conc. }]=250 \mathrm{mg} / \mathrm{L}} \\
\mathrm{T}=25 \mathrm{~min}\end{array}$ & $51.020 \mathrm{mg} / \mathrm{g}$ & Pseudo-second order /Freundlich & \\
\hline GO & Cross-linked GO with alganite & $\begin{array}{l}\mathrm{Cr}(\mathrm{III}) \\
\mathrm{Pb}(\mathrm{II})\end{array}$ & $\begin{array}{l}\mathrm{pH}=6 \\
\text { [conc.] }=80 \mathrm{mg} / \mathrm{L} \\
\mathrm{T}=56 \mathrm{~h} \\
\mathrm{pH}=5 \\
\text { [conc.] }=80 \mathrm{mg} / \mathrm{L} \\
\mathrm{T}=70 \mathrm{~h}\end{array}$ & $\begin{array}{l}327.9 \mathrm{mg} / \mathrm{g} \\
118.6 \mathrm{mg} / \mathrm{g}\end{array}$ & Pseudo-second order /Langmuir & [104] \\
\hline
\end{tabular}

$*$ [conc.]; initial concentration of metal ions, $* \mathrm{~T}=$ contact time 
In another study done by Ngambia and the group, the fabricated AC-supported $\mathrm{MgO}$ composite shows the adsorption by ion exchange between the $\mathrm{Mg}$ (II) and the metal ions ( $\mathrm{Pb}(\mathrm{II})$ and $\mathrm{Cd}(\mathrm{II})$ ), electrostatic attraction, chemical adsorption as well as precipitation effects [90].

For the ion exchange mechanism between the functional groups of the CNTs with metal ions, the divalent metal ions are attached to the acid-modified CNTs. The metal ions are adsorbed onto the active site of the CNTs and simultaneously discharge the $\mathrm{H}^{+}$ions from the surface. Therefore, the solution $\mathrm{pH}$ decreases. This process is highly dependent on the concentration of the initial heavy metal ions. The amount of the ions adsorbed onto the CNTs is increased with the initial concentration of metal ions increasing, and at the same time, the solution $\mathrm{pH}$ decreases [31]. In another approach, the interaction mechanism for the $\mathrm{Cd}(\mathrm{II})$ adsorption onto $\mathrm{CNTs} / \mathrm{Al}_{2} \mathrm{O}_{3}$ occurs via physical interactions, electrostatic interactions, and van der Waals interactions. It is believed that adsorption occurs by a combination of the mechanisms mentioned [91]. In another study conducted by Zhan and the group, many oxygencontaining groups $(-\mathrm{OH}$ and $-\mathrm{COOH})$ located at the $\mathrm{GO}$ edge would give a negative charge to attach the positive charge of metal ions through electrostatic interactions [52].

\section{Application of Carbon-based Materials in Heavy Metal Removal}

Many recent articles have been conducted on the absorption capacity of metal ions through carbon absorbents. For example, the fabrication of iron-oxide-filled MWCNTs is successfully fabricated to remove various metal ions [93]. Based on the analysis, it was depicted that the percentage removal of the $\mathrm{Cr}(\mathrm{VI}), \mathrm{Pb}(\mathrm{II}), \mathrm{Cu}(\mathrm{II})$, and $\mathrm{Fe}$ (II) can be reached up to $94 \%$. Zbair and the member fabricated carbon microspheres as an adsorbent for the removal of $\mathrm{Pb}$ (II) and $\mathrm{Cr}$ (III) metal ions. From these findings, it was found that higher adsorption reached $638 \mathrm{mg} / \mathrm{g}$ and $792 \mathrm{mg} / \mathrm{g}$, respectively [87]. A summary of selected recent studies evaluating the ability of carbon-based materials in terms of their maximum adsorption capacities, optimum conditions for adsorption process, types of modifications, the best-fit kinetic and isotherm models in heavy metals removal can be found in Table 4.

\section{Conclusions}

Carbon adsorbents' adsorption mechanisms, including electrostatic interaction, ion exchange, surface complexation, precipitation, and physical adsorption towards heavy metals removal, are highly correlated. Based on the previous studies outlined in the previous section, carbon materials such as GO, CNTs (SWCNTs, MWCNTs), AC, and biochar with modified active sites surfaces are highlighted as favorable adsorbents for various types of metal ions. In addition, different adsorption mechanisms are suitable for various types of adsorbates that are strongly influenced by the functional groups attached to the active surface of the carbonabsorbing site. In the future, due to its promising properties and good performance of carbonbased materials, its applications can be explored in various sectors such as wastewater treatment plants and environmental fields.

\section{Funding}

This research was funded by the Ministry of Higher Education under Collaboration Research Grant National 08G22 and 4B451 (Universiti Teknologi Malaysia), and Internal Grant RDU210314 (Universiti Malaysia Pahang). 


\section{Acknowledgments}

The authors would like to thank the Ministry of Higher Education, Universiti Teknologi Malaysia, and Universiti Malaysia Pahang for the funding of the project.

\section{Conflicts of Interest}

The authors declare no conflict of interest.

\section{References}

1. Teow, Y.H.; Kam, L.M.; Mohammad, A.W. Synthesis of cellulose hydrogel for copper (II) ions adsorption. J. Environ. Chem. Eng. 2018, 6, 4588-4597, https://doi.org/10.1016/j.jece.2018.07.010.

2. Wang, Z.; Tan, K.; Cai, J.; Hou, S.; Wang, Y.; Jiang, P.; Liang, M. Silica oxide encapsulated natural zeolite for high efficiency removal of low concentration heavy metals in water. Colloids Surfaces A Physicochem. Eng. Asp. 2019, 561, 388-394, https://doi.org/10.1016/j.colsurfa.2018.10.065.

3. Jing, Q.; Wang, Y.; Chai, L.; Tang, C.; Huang, X.; Guo, H.; Wang, W.; You, W. Adsorption of copper ions on porous ceramsite prepared by diatomite and tungsten residue. Trans. Nonferrous Met. Soc. China 2018, 28, 1053-1060, https://doi.org/10.1016/S1003-6326(18)64731-4.

4. Lei, C.; Gao, J.; Ren, W.; Xie, Y.; Abdalkarim, S.Y.H.; Wang, S.; Ni, W.; Yao, J. Fabrication of metalorganic frameworks@cellulose aerogels composite materials for removal of heavy metal ions in water. Carbohydr. Polym. 2019, 205, 35-41, https://doi.org/10.1016/j.carbpol.2018.10.029.

5. Li, Z.; Wu, L.; Sun, S.; Gao, J.; Zhang, H.; Zhang, Z.; Wang, Z. Disinfection and removal performance for Escherichia coli, toxic heavy metals and arsenic by wood vinegar-modified zeolite. Ecotoxicol. Environ. Saf. 2019, 174, 129-136, https://doi.org/10.1016/j.ecoenv.2019.01.124.

6. Sulaiman, K.O.; Sajid, M.; Alhooshani, K. Application of porous membrane bag enclosed alkaline treated Y-Zeolite for removal of heavy metal ions from water. Microchem. J. 2020, 152, 104289, https://doi.org/10.1016/j.microc.2019.104289.

7. Joseph, L.; Jun, B.-M.; Flora, J.R.V.; Park, C.M.; Yoon, Y. Removal of heavy metals from water sources in the developing world using low-cost materials: A review. Chemosphere 2019, 229, 142-159, https://doi.org/10.1016/j.chemosphere.2019.04.198.

8. Muhamad, N.; Abdullah, N.; Rahman, M.A.; Abas, K.H.; Aziz, A.A.; Othman, M.H.D.; Jaafar, J.; Ismail, A.F. Removal of nickel from aqueous solution using supported zeolite-Y hollow fiber membranes. Environ. Sci. Pollut. Res. 2018, 25, 19054-19064, https://doi.org/10.1007/s11356-018-2074-3.

9. Giwa, A.; Akther, N.; Dufour, V.; Hasan, S.W. A critical review on recent polymeric and nano-enhanced membranes for reverse osmosis. RSC Adv. 2016, 6, 8134-8163, https://doi.org/10.1039/C5RA17221G.

10. Murić, A.; Petrinić, I.; Christensen, M.L. Comparison of ceramic and polymeric ultrafiltration membranes for treating wastewater from metalworking industry. Chem. Eng. J. 2014, 255, 403-410, https://doi.org/10.1016/j.cej.2014.06.009.

11. Bano, S.; Mahmood, A.; Kim, S.-J.; Lee, K.-H. Graphene oxide modified polyamide nanofiltration membrane with improved flux and antifouling properties. J. Mater. Chem. A 2015, 3, 2065-2071, https://doi.org/10.1039/C4TA03607G.

12. Raouf MS, A.; Raheim ARM, A. Removal of Heavy Metals from Industrial Waste Water by Biomass-Based Materials: A Review. J. Pollut. Eff. Control 2016, 5, https://doi.org/10.4172/2375-4397.1000180.

13. Fu, F.; Wang, Q. Removal of heavy metal ions from wastewaters: A review. J. Environ. Manage. 2011, 92, 407-418, https://doi.org/10.1016/j.jenvman.2010.11.011.

14. Allafchian, A.R.; Shiasi, A.; Amiri, R. Preparing of poly(acrylonitrile co maleic acid) nanofiber mats for removal of $\mathrm{Ni}(\mathrm{II})$ and $\mathrm{Cr}(\mathrm{VI})$ ions from water. J. Taiwan Inst. Chem. Eng. 2017, 80, 563-569, https://doi.org/10.1016/j.jtice.2017.08.029.

15. Fiyadh, S.S.; AlSaadi, M.A.; Jaafar, W.Z.; AlOmar, M.K.; Fayaed, S.S.; Mohd, N.S.; Hin, L.S.; El-Shafie, A. Review on heavy metal adsorption processes by carbon nanotubes. J. Clean. Prod. 2019, 230, 783-793, https://doi.org/10.1016/j.jclepro.2019.05.154.

16. Ociński, D.; Jacukowicz-Sobala, I.; Mazur, P.; Raczyk, J.; Kociołek-Balawejder, E. Water treatment residuals containing iron and manganese oxides for arsenic removal from water - Characterization of 
physicochemical properties and adsorption studies. Chem. Eng. J. 2016, 294, 210-221, https://doi.org/10.1016/j.cej.2016.02.111.

17. Zhang, Y.; Liu, H.; Dai, X.; Wang, J.; Shen, Y.; Wang, P. The release of organic matter, nitrogen, phosphorus and heavy metals from erythromycin fermentation residue under heat-activated persulfate oxidation conditioning. Sci. Total Environ. 2020, 724, 138349, https://doi.org/10.1016/j.scitotenv.2020.138349.

18. Bora, A.J.; Dutta, R.K. Removal of metals ( $\mathrm{Pb}, \mathrm{Cd}, \mathrm{Cu}, \mathrm{Cr}, \mathrm{Ni}$, and $\mathrm{Co}$ ) from drinking water by oxidationcoagulation-absorption at optimized pH. J. Water Process Eng. 2019, 31, 100839, https://doi.org/10.1016/j.jwpe.2019.100839.

19. Yuan, J.; Zhang, W.; Xiao, Z.; Zhou, X.; Zeng, Q. +Efficient dewatering and heavy-metal removal in municipal sewage using oxidants. Chem. Eng. J. 2020, 388, 124298, https://doi.org/10.1016/j.cej.2020.124298.

20. He, M.; Wang, L.; Lv, Y.; Wang, X.; Zhu, J.; Zhang, Y.; Liu, T. Novel polydopamine/metal organic framework thin film nanocomposite forward osmosis membrane for salt rejection and heavy metal removal. Chem. Eng. J. 2020, 389, 124452, https://doi.org/10.1016/j.cej.2020.124452.

21. Samaei, S.M.; Gato-Trinidad, S.; Altaee, A. Performance evaluation of reverse osmosis process in the posttreatment of mining wastewaters: Case study of Costerfield mining operations, Victoria, Australia. J. Water Process Eng. 2020, 34, 101116, https://doi.org/10.1016/j.jwpe.2019.101116.

22. Saeedi-Jurkuyeh, A.; Jafari, A.J.; Kalantary, R.R.; Esrafili, A. A novel synthetic thin-film nanocomposite forward osmosis membrane modified by graphene oxide and polyethylene glycol for heavy metals removal from aqueous solutions. React. Funct. Polym. 2020, 146, 104397, https://doi.org/10.1016/j.reactfunctpolym.2019.104397.

23. Abdullah, W.N.A.S.; Tiandee, S.; Lau, W.; Aziz, F.; Ismail, A.F. Potential use of nanofiltration like-forward osmosis membranes for copper ion removal. Chinese J. Chem. Eng. 2020, 28, 420-428, https://doi.org/10.1016/j.cjche.2019.05.016.

24. Araucz, K.; Aurich, A.; Kołodyńska, D. Novel multifunctional ion exchangers for metal ions removal in the presence of citric acid. Chemosphere 2020, 251, https://doi.org/10.1016/j.chemosphere.2020.126331.

25. Maslova, M.; Ivanenko, V.; Yanicheva, N.; Gerasimova, L. The effect of heavy metal ions hydration on their sorption by a mesoporous titanium phosphate ion-exchanger. J. Water Process Eng. 2020, 35, 101233, https://doi.org/10.1016/j.jwpe.2020.101233.

26. Kołodyńska, D.; Fila, D.; Hubicki, Z. Evaluation of possible use of the macroporous ion exchanger in the adsorption process of rare earth elements and heavy metal ions from spent batteries solutions. Chem. Eng. Process. - Process Intensif. 2020, 147, 107767, https://doi.org/10.1016/j.cep.2019.107767.

27. Li, X.; Zhang, Q.; Yang, B. Co-precipitation with $\mathrm{CaCO} 3$ to remove heavy metals and significantly reduce the moisture content of filter residue. Chemosphere 2020, 239, 124660, https://doi.org/10.1016/j.chemosphere.2019.124660.

28. Eggermont, S.G.F.; Prato, R.; Dominguez-Benetton, X.; Fransaer, J. Metal removal from aqueous solutions: insights from modeling precipitation titration curves. J. Environ. Chem. Eng. 2020, 8, 103596, https://doi.org/10.1016/j.jece.2019.103596.

29. Ou, B.; Wang, J.; Wu, Y.; Zhao, S.; Wang, Z. Efficient removal of Cr (VI) by magnetic and recyclable calcined CoFe-LDH/g-C3N4 via the synergy of adsorption and photocatalysis under visible light. Chem. Eng. J. 2020, 380, 122600, https://doi.org/10.1016/j.cej.2019.122600.

30. Liang, H.; Li, T.; Zhang, J.; Zhou, D.; Hu, C.; An, X.; Liu, R.; Liu, H. 3-D hierarchical Ag/ZnO@CF for synergistically removing phenol and $\mathrm{Cr}(\mathrm{VI})$ : Heterogeneous vs. homogeneous photocatalysis. J. Colloid Interface Sci. 2020, 558, 85-94, https://doi.org/10.1016/j.jcis.2019.09.105.

31. Ihsanullah; Abbas, A.; Al-Amer, A.M.; Laoui, T.; Al-Marri, M.J.; Nasser, M.S.; Khraisheh, M.; Atieh, M.A. Heavy metal removal from aqueous solution by advanced carbon nanotubes: Critical review of adsorption applications. Sep. Purif. Technol. 2016, 157, 141-161, https://doi.org/10.1016/j.seppur.2015.11.039.

32. Taleb, K.; Markovski, J.; Veličković, Z.; Rusmirović, J.; Rančić, M.; Pavlović, V.; Marinković, A. Arsenic removal by magnetite-loaded amino modified nano/microcellulose adsorbents: Effect of functionalization and media size. Arab. J. Chem. 2019, 12, 4675-4693, https://doi.org/10.1016/j.arabjc.2016.08.006.

33. Mokgehle, T.M.; Gitari, W.M.; Tavengwa, N.T. Synthesis of di-carboxylic acid functionalized zeolites from coal fly ash for Cd (II) removal from acid mine drainage using column studies approach. J. Environ. Chem. Eng. 2019, 7, 103473, https://doi.org/10.1016/j.jece.2019.103473. 
34. Bediako, J.K.; Wei, W.; Yun, Y.-S. Conversion of waste textile cellulose fibers into heavy metal adsorbents. J. Ind. Eng. Chem. 2016, 43, 61-68, https://doi.org/10.1016/j.jiec.2016.07.048.

35. Chitpong, N.; Husson, S.M. Polyacid functionalized cellulose nanofiber membranes for removal of heavy metals from impaired waters. J. Memb. Sci. 2017, 523, 418-429, https://doi.org/10.1016/j.memsci.2016.10.020.

36. Tangtubtim, S.; Saikrasun, S. Adsorption behavior of polyethyleneimine-carbamate linked pineapple leaf fiber for $\mathrm{Cr}(\mathrm{VI})$ removal. Appl. Surf. Sci. 2019, 467-468, 596-607, https://doi.org/10.1016/j.apsusc.2018.10.204.

37. Sánchez, J.; Espinosa, C.; Tapiero, Y.; Santiago-García, J.L.; Oyarzún, D.P.; Pizarro, G. del C. Modification of regenerated cellulose membranes with cationic polymer and its $\mathrm{Cr}(\mathrm{VI})$ retention capacity. J. Water Process Eng. 2019, 30, 100619, https://doi.org/10.1016/j.jwpe.2018.04.016.

38. Ogata, F.; Ueta, E.; Kawasaki, N. Characteristics of a novel adsorbent Fe-Mg-type hydrotalcite and its adsorption capability of $\mathrm{As}(\mathrm{III})$ and $\mathrm{Cr}(\mathrm{VI})$ from aqueous solution. J. Ind. Eng. Chem. 2018, 59, 56-63, https://doi.org/10.1016/j.jiec.2017.10.005.

39. Periyasamy, S.; Gopalakannan, V.; Viswanathan, N. Fabrication of magnetic particles imprinted cellulose based biocomposites for chromium(VI) removal. Carbohydr. Polym. 2017, 174, 352-359, https://doi.org/10.1016/j.carbpol.2017.06.029.

40. Marques, J.G.O.; Costa, A.L.; Pereira, C. Na-O-H thermochemical water splitting cycle: A new approach in hydrogen production based on sodium cooled fast reactor. Int. J. Hydrogen Energy 2018, 43, 7738-7753, https://doi.org/10.1016/j.ijhydene.2018.03.027.

41. Ali, R.M.; Hamad, H.A.; Hussein, M.M.; Malash, G.F. Potential of using green adsorbent of heavy metal removal from aqueous solutions: Adsorption kinetics, isotherm, thermodynamic, mechanism and economic analysis. Ecol. Eng. 2016, 91, 317-332, https://doi.org/10.1016/j.ecoleng.2016.03.015.

42. Thanh, D.N.; Novák, P.; Vejpravova, J.; Vu, H.N.; Lederer, J.; Munshi, T. Removal of copper and nickel from water using nanocomposite of magnetic hydroxyapatite nanorods. J. Magn. Magn. Mater. 2018, 456, 451-460, https://doi.org/10.1016/j.jmmm.2017.11.064.

43. Shariful, M.I.; Sharif, S. Bin; Lee, J.J.L.; Habiba, U.; Ang, B.C.; Amalina, M.A. Adsorption of divalent heavy metal ion by mesoporous-high surface area chitosan/poly (ethylene oxide) nanofibrous membrane. Carbohydr. Polym. 2017, 157, 57-64, https://doi.org/10.1016/j.carbpol.2016.09.063.

44. Dong, C.; Zhang, F.; Pang, Z.; Yang, G. Efficient and selective adsorption of multi-metal ions using sulfonated cellulose as adsorbent. Carbohydr. Polym. 2016, 151, 230-236, https://doi.org/10.1016/j.carbpol.2016.05.066.

45. Tran, T.H.; Okabe, H.; Hidaka, Y.; Hara, K. Removal of metal ions from aqueous solutions using carboxymethyl cellulose/sodium styrene sulfonate gels prepared by radiation grafting. Carbohydr. Polym. 2017, 157, 335-343, https://doi.org/10.1016/j.carbpol.2016.09.049.

46. Zhang, Y.; Zhang, S.; Gao, J.; Chung, T.-S. Layer-by-layer construction of graphene oxide (GO) framework composite membranes for highly efficient heavy metal removal. J. Memb. Sci. 2016, 515, 230-237, https://doi.org/10.1016/j.memsci.2016.05.035.

47. Tang, H.; Chang, C.; Zhang, L. Efficient adsorption of Hg2+ ions on chitin/cellulose composite membranes prepared via environmentally friendly pathway. Chem. Eng. J. 2011, 173, 689-697, https://doi.org/10.1016/j.cej.2011.07.045.

48. Kumari, S.; Chauhan, G.S. New Cellulose-Lysine Schiff-Base-Based Sensor-Adsorbent for Mercury Ions. ACS Appl. Mater. Interfaces 2014, 6, 5908-5917, https://doi.org/10.1021/am500820n.

49. Anirudhan, T.S.; Shainy, F. Effective removal of mercury(II) ions from chlor-alkali industrial wastewater using 2-mercaptobenzamide modified itaconic acid-grafted-magnetite nanocellulose composite. J. Colloid Interface Sci. 2015, 456, 22-31, https://doi.org/10.1016/j.jcis.2015.05.052.

50. Etxeberria-Benavides, M.; Johnson, T.; Cao, S.; Zornoza, B.; Coronas, J.; Sanchez-Lainez, J.; Sabetghadam, A.; Liu, X.; Andres-Garcia, E.; Kapteijn, F.; et al. PBI mixed matrix hollow fiber membrane: Influence of ZIF-8 filler over $\mathrm{H}_{2} / \mathrm{CO}_{2}$ separation performance at high temperature and pressure. Sep. Purif. Technol. 2020, 237, 116347, https://doi.org/10.1016/j.seppur.2019.116347.

51. Moallaei, H.; Bouchara, J.-P.; Rad, A.; Singh, P.; Raizada, P.; Tran, H.N.; Zafar, M.N.; Giannakoudakis, D.A.; Hosseini-Bandegharaei, A. Application of Fusarium sp. immobilized on multi-walled carbon nanotubes for solid-phase extraction and trace analysis of heavy metal cations. Food Chem. 2020, 322, 126757, https://doi.org/10.1016/j.foodchem.2020.126757. 
52. Zhan, W.; Gao, L.; Fu, X.; Siyal, S.H.; Sui, G.; Yang, X. Green synthesis of amino-functionalized carbon nanotube-graphene hybrid aerogels for high performance heavy metal ions removal. Appl. Surf. Sci. 2019, 467-468, 1122-1133, https://doi.org/10.1016/j.apsusc.2018.10.248.

53. Sadeghi, M.H.; Tofighy, M.A.; Mohammadi, T. One-dimensional graphene for efficient aqueous heavy metal adsorption: Rapid removal of arsenic and mercury ions by graphene oxide nanoribbons (GONRs). Chemosphere 2020, 253, 126647, https://doi.org/10.1016/j.chemosphere.2020.126647.

54. Vijayalakshmi, K.; Gomathi, T.; Latha, S.; Hajeeth, T.; Sudha, P.N. Removal of copper(II) from aqueous solution using nanochitosan/sodium alginate/microcrystalline cellulose beads. Int. J. Biol. Macromol. 2016, 82, 440-452, https://doi.org/10.1016/j.ijbiomac.2015.09.070.

55. Garba, Z.N.; Lawan, I.; Zhou, W.; Zhang, M.; Wang, L.; Yuan, Z. Microcrystalline cellulose (MCC) based materials as emerging adsorbents for the removal of dyes and heavy metals - A review. Sci. Total Environ. 2020, 717, 135070, https://doi.org/10.1016/j.scitotenv.2019.135070.

56. Hou, T.; Yan, L.; Li, J.; Yang, Y.; Shan, L.; Meng, X.; Li, X.; Zhao, Y. Adsorption performance and mechanistic study of heavy metals by facile synthesized magnetic layered double oxide/carbon composite from spent adsorbent. Chem. Eng. J. 2020, 384, 123331, https://doi.org/10.1016/j.cej.2019.123331.

57. Ben-Ali, S.; Jaouali, I.; Souissi-Najar, S.; Ouederni, A. Characterization and adsorption capacity of raw pomegranate peel biosorbent for copper removal. J. Clean. Prod. 2017, 142, 3809-3821, https://doi.org/10.1016/j.jclepro.2016.10.081.

58. Chaabane, L.; Beyou, E.; El Ghali, A.; Baouab, M.H. V. Comparative studies on the adsorption of metal ions from aqueous solutions using various functionalized graphene oxide sheets as supported adsorbents. $J$. Hazard. Mater. 2020, 389, 121839, https://doi.org/10.1016/j.jhazmat.2019.121839.

59. Liu, C.; Jin, R.-N.; Ouyang, X.; Wang, Y.-G. Adsorption behavior of carboxylated cellulose nanocrystalpolyethyleneimine composite for removal of $\mathrm{Cr}(\mathrm{VI})$ ions. Appl. Surf. Sci. 2017, 408, 77-87, https://doi.org/10.1016/j.apsusc.2017.02.265.

60. Lim, H.K.; Teng, T.T.; Ibrahim, M.H.; Ahmad, A.; Chee, H.T. Adsorption and Removal of Zinc (II) from Aqueous Solution Using Powdered Fish Bones. APCBEE Procedia 2012, 1, 96-102, https://doi.org/10.1016/j.apcbee.2012.03.017.

61. Tran, T.H.; Okabe, H.; Hidaka, Y.; Hara, K. Removal of metal ions from aqueous solutions using carboxymethyl cellulose/sodium styrene sulfonate gels prepared by radiation grafting. Carbohydr. Polym. 2017, 157, 335-343, https://doi.org/10.1016/j.carbpol.2016.09.049.

62. Zhang, J.; Fu, H.; Lv, X.; Tang, J.; Xu, X. Removal of $\mathrm{Cu}(\mathrm{II})$ from aqueous solution using the rice husk carbons prepared by the physical activation process. Biomass and Bioenergy 2011, 35, 464-472, https://doi.org/10.1016/j.biombioe.2010.09.002.

63. Yang, X.; Wan, Y.; Zheng, Y.; He, F.; Yu, Z.; Huang, J.; Wang, H.; Ok, Y.S.; Jiang, Y.; Gao, B. Surface functional groups of carbon-based adsorbents and their roles in the removal of heavy metals from aqueous solutions: A critical review. Chem. Eng. J. 2019, 366, 608-621, https://doi.org/10.1016/j.cej.2019.02.119.

64. Liu, T.-Y.; Yuan, H.-G.; Li, Q.; Tang, Y.-H.; Zhang, Q.; Qian, W.; Van der Bruggen, B.; Wang, X. IonResponsive Channels of Zwitterion-Carbon Nanotube Membrane for Rapid Water Permeation and Ultrahigh Mono-/Multivalent Ion Selectivity. ACS Nano 2015, 9, 7488-7496, https://doi.org/10.1021/acsnano.5b02598.

65. Buffa, A.; Mandler, D. Adsorption and detection of organic pollutants by fixed bed carbon nanotube electrochemical membrane. Chem. Eng. J. 2019, 359, 130-137, https://doi.org/10.1016/j.cej.2018.11.069.

66. Mahlangu, O.T.; Nackaerts, R.; Thwala, J.M.; Mamba, B.B.; Verliefde, A.R.D. Hydrophilic fouling-resistant GO-ZnO/PES membranes for wastewater reclamation. J. Memb. Sci. 2017, 524, 43-55, https://doi.org/10.1016/j.memsci.2016.11.018.

67. Wang, C.; Chen, L.; Liu, S. Activated carbon fiber for adsorption/electrodeposition of $\mathrm{Cu}$ (II) and the recovery of $\mathrm{Cu}(0)$ by controlling the applied voltage during membrane capacitive deionization. J. Colloid Interface Sci. 2019, 548, 160-169, https://doi.org/10.1016/j.jcis.2019.04.030.

68. Dong, Q.; Wang, G.; Qian, B.; Hu, C.; Wang, Y.; Qiu, J. Electrospun Composites Made of Reduced Graphene Oxide and Activated Carbon Nanofibers for Capacitive Deionization. Electrochim. Acta 2014, 137, 388-394, https://doi.org/10.1016/j.electacta.2014.06.067.

69. Hadi, P.; Xu, M.; Ning, C.; Sze Ki Lin, C.; McKay, G. A critical review on preparation, characterization and utilization of sludge-derived activated carbons for wastewater treatment. Chem. Eng. J. 2015, 260, 895-906, https://doi.org/10.1016/j.cej.2014.08.088. 
70. Rahmani-Sani, A.; Singh, P.; Raizada, P.; Claudio Lima, E.; Anastopoulos, I.; Giannakoudakis, D.A.; Sivamani, S.; Dontsova, T.A.; Hosseini-Bandegharaei, A. Use of chicken feather and eggshell to synthesize a novel magnetized activated carbon for sorption of heavy metal ions. Bioresour. Technol. 2020, 297, 122452, https://doi.org/10.1016/j.biortech.2019.122452.

71. Zaini, M.A.A.; Zhi, L.L.; Hui, T.S.; Amano, Y.; Machida, M. Effects of physical activation on pore textures and heavy metals removal of fiber-based activated carbons. Mater. Today Proc. 2021, 39, 917-921, https://doi.org/10.1016/j.matpr.2020.03.815.

72. Kundu, A.; Redzwan, G.; Sahu, J.N.; Mukherjee, S.; Gupta, B.S.; Hashim, M.A. Hexavalent chromium adsorption by a novel activated carbon prepared by microwave activation. BioRes. 2014, 9, 1498 - 1518.

73. Burakov, A.E.; Galunin, E. V.; Burakova, I. V.; Kucherova, A.E.; Agarwal, S.; Tkachev, A.G.; Gupta, V.K. Adsorption of heavy metals on conventional and nanostructured materials for wastewater treatment purposes: A review. Ecotoxicol. Environ. Saf. 2018, 148, 702-712, https://doi.org/10.1016/j.ecoenv.2017.11.034.

74. Liu, C.; Cheng, H.-M. Carbon nanotubes: controlled growth and application. Mater. Today 2013, 16, 19-28, https://doi.org/10.1016/j.mattod.2013.01.019.

75. Yang, Z.-F.; Li, L.-Y.; Hsieh, C.-T.; Juang, R.-S.; Gandomi, Y.A. Fabrication of magnetic iron Oxide@Graphene composites for adsorption of copper ions from aqueous solutions. Mater. Chem. Phys. 2018, 219, 30-39, https://doi.org/10.1016/j.matchemphys.2018.07.053.

76. Manawi, Y.; Kochkodan, V.; Hussein, M.A.; Khaleel, M.A.; Khraisheh, M.; Hilal, N. Can carbon-based nanomaterials revolutionize membrane fabrication for water treatment and desalination? Desalination 2016, 391, 69-88, https://doi.org/10.1016/j.desal.2016.02.015.

77. Rajakumar, G.; Zhang, X.-H.; Gomathi, T.; Wang, S.-F.; Azam Ansari, M.; Mydhili, G.; Nirmala, G.; Alzohairy, M.A.; Chung, I.-M. Current Use of Carbon-Based Materials for Biomedical Applications-A Prospective and Review. Processes 2020, 8, 355, https://doi.org/10.3390/pr8030355.

78. Zhang, Y.; Liu, Y.; Wang, X.; Sun, Z.; Ma, J.; Wu, T.; Xing, F.; Gao, J. Porous graphene oxide/carboxymethyl cellulose monoliths, with high metal ion adsorption. Carbohydr. Polym. 2014, 101, 392-400, https://doi.org/10.1016/j.carbpol.2013.09.066.

79. Yao, N.; Li, C.; Yu, J.; Xu, Q.; Wei, S.; Tian, Z.; Yang, Z.; Yang, W.; Shen, J. Insight into adsorption of combined antibiotic-heavy metal contaminants on graphene oxide in water. Sep. Purif. Technol. 2020, 236, 116278, https://doi.org/10.1016/j.seppur.2019.116278.

80. Ćosić, M.; Petrović, S.; Nešković, N. Quantum Rainbows in Positron Transmission through Carbon Nanotubes. Atoms 2019, 7, 16, https://doi.org/10.3390/atoms7010016.

81. Zhao, Y.-L.; Stoddart, J.F. Noncovalent Functionalization of Single-Walled Carbon Nanotubes. Acc. Chem. Res. 2009, 42, 1161-1171, https://doi.org/10.1021/ar900056z.

82. Agnihotri, S.; Mota, J.P.B.; Rostam-Abadi, M.; Rood, M.J. Theoretical and Experimental Investigation of Morphology and Temperature Effects on Adsorption of Organic Vapors in Single-Walled Carbon Nanotubes. J. Phys. Chem. B 2006, 110, 7640-7647, https://doi.org/10.1021/jp060040a.

83. Shen, J. nan; Yu, C. chao; Ruan, H. min; Gao, C. jie; Van der Bruggen, B. Preparation and characterization of thin-film nanocomposite membranes embedded with poly(methyl methacrylate) hydrophobic modified multiwalled carbon nanotubes by interfacial polymerization. J. Memb. Sci. 2013, 442, 18-26, https://doi.org/10.1016/j.memsci.2013.04.018.

84. Vatanpour, V.; Madaeni, S.S.; Moradian, R.; Zinadini, S.; Astinchap, B. Fabrication and characterization of novel antifouling nanofiltration membrane prepared from oxidized multiwalled carbon nanotube/polyethersulfone nanocomposite. J. Memb. Sci. 2011, 375, 284-294, https://doi.org/10.1016/j.memsci.2011.03.055.

85. Yin, J.; Zhu, G.; Deng, B. Multi-walled carbon nanotubes (MWNTs)/polysulfone (PSU) mixed matrix hollow fiber membranes for enhanced water treatment. J. Memb. Sci. 2013, 437, 237-248, https://doi.org/10.1016/j.memsci.2013.03.021.

86. Anantha, R.K.; Kota, S. Removal of lead by adsorption with the renewable biopolymer composite of feather (Dromaius novaehollandiae) and chitosan (Agaricus bisporus). Environ. Technol. Innov. 2016, 6, 11-26, https://doi.org/10.1016/j.eti.2016.04.004.

87. Zbair, M.; Ait Ahsaine, H.; Anfar, Z.; Slassi, A. Carbon microspheres derived from walnut shell: Rapid and remarkable uptake of heavy metal ions, molecular computational study and surface modeling. Chemosphere 2019, 231, 140-150, https://doi.org/10.1016/j.chemosphere.2019.05.120. 
88. Eeshwarasinghe, D.; Loganathan, P.; Vigneswaran, S. Simultaneous removal of polycyclic aromatic hydrocarbons and heavy metals from water using granular activated carbon. Chemosphere 2019, 223, 616627, https://doi.org/10.1016/j.chemosphere.2019.02.033.

89. Tofighy, M.A.; Mohammadi, T. Divalent heavy metal ions removal from contaminated water using positively charged membrane prepared from a new carbon nanomaterial and HPEI. Chem. Eng. J. 2020, 388, 124192, https://doi.org/10.1016/j.cej.2020.124192.

90. Ngambia, A.; Ifthikar, J.; Shahib, I.I.; Jawad, A.; Shahzad, A.; Zhao, M.; Wang, J.; Chen, Z.; Chen, Z. Adsorptive purification of heavy metal contaminated wastewater with sewage sludge derived carbonsupported $\mathrm{Mg}$ (II) composite. Sci. Total Environ. 2019, 691, 306-321, https://doi.org/10.1016/j.scitotenv.2019.07.003.

91. Liang, J.; Liu, J.; Yuan, X.; Dong, H.; Zeng, G.; Wu, H.; Wang, H.; Liu, J.; Hua, S.; Zhang, S.; et al. Facile synthesis of alumina-decorated multi-walled carbon nanotubes for simultaneous adsorption of cadmium ion and trichloroethylene. Chem. Eng. J. 2015, 273, 101-110, https://doi.org/10.1016/j.cej.2015.03.069.

92. Rao, G.; Lu, C.; Su, F. Sorption of divalent metal ions from aqueous solution by carbon nanotubes: A review. Sep. Purif. Technol. 2007, 58, 224-231, https://doi.org/10.1016/j.seppur.2006.12.006.

93. Ranjan, B.; Pillai, S.; Permaul, K.; Singh, S. Simultaneous removal of heavy metals and cyanate in a wastewater sample using immobilized cyanate hydratase on magnetic-multiwall carbon nanotubes. $J$. Hazard. Mater. 2019, 363, 73-80, https://doi.org/10.1016/j.jhazmat.2018.07.116.

94. Yunus, Z.M.; Al-Gheethi, A.; Othman, N.; Hamdan, R.; Ruslan, N.N. Removal of heavy metals from mining effluents in tile and electroplating industries using honeydew peel activated carbon: A microstructure and techno-economic analysis. J. Clean. Prod. 2020, 251, https://doi.org/10.1016/j.jclepro.2019.119738.

95. Kharrazi, S.M.; Mirghaffari, N.; Dastgerdi, M.M.; Soleimani, M. A novel post-modification of powdered activated carbon prepared from lignocellulosic waste through thermal tension treatment to enhance the porosity and heavy metals adsorption. Powder Technol. 2020, 366, 358-368, https://doi.org/10.1016/j.powtec.2020.01.065.

96. Ghasemi, E.; Heydari, A.; Sillanpää, M. Ultrasonic assisted adsorptive removal of toxic heavy metals from environmental samples using functionalized silica-coated magnetic multiwall carbon nanotubes (MagMWCNTs@SiO2). Eng. Agric. Environ. Food 2019, 12, 435-442, https://doi.org/10.1016/j.eaef.2019.07.002.

97. Cao, F.; Lian, C.; Yu, J.; Yang, H.; Lin, S. Study on the adsorption performance and competitive mechanism for heavy metal contaminants removal using novel multi-pore activated carbons derived from recyclable long-root Eichhornia crassipes. Bioresour. Technol. 2019, 276, 211-218, https://doi.org/10.1016/j.biortech.2019.01.007.

98. Shi, Y.; Zheng, W.; Liu, H.; Wang, L.; Zhang, H. Protein-derived nitrogen and sulfur co-doped carbon for efficient adsorptive removal of heavy metals. Chinese J. Chem. Eng. 2019, 27, 2581-2586, https://doi.org/10.1016/j.cjche.2018.11.017.

99. Marciniak, M.; Goscianska, J.; Frankowski, M.; Pietrzak, R. Optimal synthesis of oxidized mesoporous carbons for the adsorption of heavy metal ions. J. Mol. Liq. 2019, 276, 630-637, https://doi.org/10.1016/j.molliq.2018.12.042.

100. Chen, H.; Meng, Y.; Jia, S.; Hua, W.; Cheng, Y.; Lu, J.; Wang, H. Graphene oxide modified waste newspaper for removal of heavy metal ions and its application in industrial wastewater. Mater. Chem. Phys. 2020, 244, 122692, https://doi.org/10.1016/j.matchemphys.2020.122692.

101. Bulin, C.; Zhang, Y.; Li, B.; Zhang, B. Removal performance of aqueous Co(II) by magnetic graphene oxide and adsorption mechanism. J. Phys. Chem. Solids 2020, 144, 109483, https://doi.org/10.1016/j.jpcs.2020.109483.

102. Neolaka, Y.A.B.; Lawa, Y.; Naat, J.N.; Riwu, A.A.P.; Iqbal, M.; Darmokoesoemo, H.; Kusuma, H.S. The adsorption of $\mathrm{Cr}(\mathrm{VI})$ from water samples using graphene oxide-magnetic (GO-Fe3O4) synthesized from natural cellulose-based graphite (kusambi wood or Schleichera oleosa): Study of kinetics, isotherms and thermodynamics. J. Mater. Res. Technol. 2020, 9, 6544-6556, https://doi.org/10.1016/j.jmrt.2020.04.040.

103. Ain, Q.-U.-; Farooq, M.U.; Jalees, M.I. Application of Magnetic Graphene Oxide for Water Purification: Heavy Metals Removal and Disinfection. J. Water Process Eng. 2020, 33, 101044, https://doi.org/10.1016/j.jwpe.2019.101044. 
104. Bai, C.; Wang, L.; Zhu, Z. Adsorption of $\mathrm{Cr}(\mathrm{III})$ and $\mathrm{Pb}(\mathrm{II})$ by graphene oxide/alginate hydrogel membrane: Characterization, adsorption kinetics, isotherm and thermodynamics studies. Int. J. Biol. Macromol. 2020, 147, 898-910, https://doi.org/10.1016/j.ijbiomac.2019.09.249. 